\title{
Evidence for variability in the phenotypic expression of lysozyme resistance in Lactobacillus helveticus
}

\author{
M Veaux ${ }^{*}$, E Neviani 2, G Giraffa 2, J Hermier 1 \\ 1 INRA,Station de Recherches Laitières, Centre de Recherches de Jouy, \\ 78352 Jouy-en-Josas Cedex, France \\ ${ }^{2}$ Istituto Sperimentale Lattiero Caseario, Via Lombardo 11, 20075 Lodi, Italy
}

(Received 3 August 1990; accepted 16 November 1990)

\begin{abstract}
Summary - In a cell population of Lactobacillus helveticus-sensitive strains, resistance to lysozyme of individual cells varied from $10 \mu \mathrm{g} / \mathrm{ml}$ to $>500 \mu \mathrm{g} / \mathrm{ml}$ of lysozyme. The resistance to $100 \mu \mathrm{g} / \mathrm{ml}$ by successive transfers in milk with $100 \mu \mathrm{g} / \mathrm{ml}$ of lysozyme was apparently acquired by eliminating the less resistant cells and by increasing lysozyme resistance of the surviving cells. Resistance to 100 $\mu \mathrm{g} / \mathrm{ml}$ of lysozyme was also obtained in one step by growth in MRS agar containing $500 \mu \mathrm{g} / \mathrm{ml}$ of lysozyme. These results could be explained by a large variability of the phenotypic expression of resistance in each cellular line. Clones harboring a 11.5-kb plasmid were detected amongst resistant derivatives from sensitive strains which were plasmid-free. These clones exhibited properties (resistance to lysozyme, $\mathrm{NaCl}$ and antibiotic, carbohydrate fermentation and enzymatic activity patterns, phage resistance, restriction profile of total DNA) similar to those of the plasmid-free strains derived from the same sensitive parent strain. Two clones obtained after curing by novobiocin exhibited a decreased resistance to lysozyme. These results suggest that the $11.5-\mathrm{kb}$ plasmid could possibly contribute to the phenotypic expression of the resistance to lysozyme.
\end{abstract}

Lactobacillus helveticus / lysozyme resistance / variability / plasmid

Résumé - Mise en évidence d'une variabilité dans l'expression phénotypique de la résistance au lysozyme chez Lactobacillus helveticus. Dans une population cellulaire de souches sensibles de $L$ helveticus, la résistance au lysozyme des cellules individuelles varie de 10 à plus de $500 \mu \mathrm{g} / \mathrm{ml}$ de lysozyme. La résistance à $100 \mu \mathrm{g} / \mathrm{ml}$ de lysozyme obtenue par transferts successifs dans du lait contenant $100 \mu \mathrm{g} / \mathrm{ml}$ de lysozyme résulte apparemment de l'élimination progressive des cellules les moins résistantes et d'une augmentation de la résistance des cellules survivantes. La résistance de l'ensemble de la population à $100 \mu \mathrm{g} / \mathrm{ml}$ de lysozyme a été obtenue en une seule étape par culture sur une gélose MRS contenant $500 \mu \mathrm{g} / \mathrm{ml}$ de lysozyme. Ces résultats sont explicables par une importante variabilité de l'expression phénotypique de la résistance à l'intérieur d'une même lignée cellulaire. Des clones hébergeant un plasmide de $11,5 \mathrm{~kb}$ ont été détectés parmi des souches résistantes dérivées de souches sensibles dépourvues de plasmide. Ces clones montrent les mêmes propriétés (résistance au lysozyme, aux antibiotiques et au $\mathrm{NaCl}$, profils de la fermentation des sucres et des activités enzymatiques, résistance aux phages, profil de restriction de l'ADN total) que les souches dépourvues de plasmide dérivées de la même souche sensible. Deux clones obtenus après curage par la novobiocine, montrent une diminution de la résistance au lysozyme. Ces résultats laissent supposer une contribution du plasmide de $11,5 \mathrm{~kb}$ à l'expression phénotypique de la résistance au lysozyme.

Lactobacillus helveticus / résistance au lysozyme / variabilité / plasmide

* Correspondence and reprints 


\section{INTRODUCTION}

Lysozyme (EC 3.2.1.17, $\beta-1,4$ glycan hydrolase) hydrolyses glycosidic linkages between the $\mathrm{N}$-acetylmuramic acid an $\mathrm{N}$ acetylglucosamine residues of the cell wall peptidoglycan (Salton, 1961). This enzyme is a selective and effective antibacterial agent but its bactericidal or bacteriostatic properties do not always correspond with its lytic ability in vitro (lacono et al, 1980). However, the resistance to lysozyme has generally been attributed to modifications of varying nature in the chemical composition of the cell wall, eg, the presence of $a$ acetyl groups, the absence of $\mathrm{N}$-acetyl groups, attachment of teichoic acids, or the occurrence of free amino groups in the peptide portion (See Araki et al, 1972, introduction).

Few attempts have been made to produce lysozyme-resistant strains. Resistant variants of Micrococcus lysodeikticus (Litwack, 1958; Brumfitt, 1959), Bacillus megatherium (Brumfitt, 1959), Streptococcus faecalis (Brumfitt, 1959) and Lactobacillus helveticus (Neviani et al, 1988, 1991) have been obtained by serial subcultures, in a liquid medium containing a small quantity of lysozyme $(0.1-0.2 \mu \mathrm{g} / \mathrm{ml}$ ) (Litwack, 1958), in autoclaved milk containing 100 $\mu \mathrm{g} / \mathrm{ml}$ of lysozyme (Neviani et al, 1988, 1991) or on nutrient agar containing increasing amounts of lysozyme (Brumfitt, 1959). The growth rate of resistant derivatives was lower (Litwack, 1958; Brumfitt, 1959 ) than or similar (Neviani et al, 1988, 1991) to that of the parent sensitive strains.

The mechanism of resistance acquisition to lysozyme is speculative. A "heterogeneous phenotypic adaptation" (Litwack, 1958) a "genetic change" (Brumfitt, 1959) or a "strain adaptation" based on "a heterogeneity in lysozyme resistance" (Nevia- ni et al, 1991), have successively been put forward. Therefore, the first objective of the present study was to analyze the features of the increasing resistance of $L$ helveticus during serial subcultures in milk containing lysozyme in order to elucidate the mechanism involved.

Very little is known about possible plasmid-encoded functions in $L$ helveticus : protease activity (Morelli et al, 1986), Nacetyl D-glucosamine fermentation (Smiley and Fryder, 1978) and restrictionmodification systems (de los ReyesGavilan et al, 1990) are associated with the presence of a plasmid. During the present investigation on resistance to lysozyme in $L$ helveticus, plasmid profiles were routinely performed on the strains used in isolating lysozyme resistant variants. Clones harboring a 11.5-kb plasmid were detected in the cell population of some resistant derivatives. Therefore, the second aim of this study was to characterize these clones and to analyze the possible contribution of this plasmid to lysozyme resistance.

\section{MATERIALS AND METHODS}

\section{Strains, media and growth conditions}

$L$ helveticus-sensitive strains 1, 3, $4,11,13,14$, 27 and 31 (labelled S; see table I) were obtained from the stock collection of the Istituto Sperimentale Lattiero Caseario (Lodi). Derivatives of these strains are listed in table I. In preparation for experiments, all strains were grown in MRS broth (De Man et al, 1960) at $42{ }^{\circ} \mathrm{C}$ for $15-18 \mathrm{~h}$. Bacterial growth in milk with or without $100 \mu \mathrm{g} / \mathrm{ml}$ of lysozyme was evaluated by conductance measurements as described previously (Neviani et al, 1991). Overnight cultures in milk were enumerated in MRS agar plates containing different concentrations of lysozyme. The plates were incubated at $42{ }^{\circ} \mathrm{C}$ in $\mathrm{BBL}$ anaerobic jars with GASPAK $\mathrm{H}_{2}+\mathrm{CO}_{2}$. 
Table I. Strains of Lactobacillus helveticus used in this study.

Souches de Lactobacillus helveticus utilisées dans cette étude.

Strains Characteristics Description

(Ref)

$S$

$\mathrm{R} 100$

R500

R100P

R100P-
Sensitive to lysozyme

Resistant to lysozyme

$(100 \mu \mathrm{g} / \mathrm{ml})$

Resistant to lysozyme $(100 \mu \mathrm{g} / \mathrm{ml})$

Resistant to lysozyme $(100 \mu \mathrm{g} / \mathrm{ml})$, harboring

a $11.5-\mathrm{kb}$ plasmid

Cured of $11.5-\mathrm{kb}$ plasmid
Lodi-Culture Collection

(Neviani et al, 1991)

Derivatives of $S$ by successive transfers in milk $+100 \mu \mathrm{g} / \mathrm{ml}$ of lysozyme (Neviani et al, 1991)

Derivatives of $\mathrm{S}$ by growth on MRS agar $+500 \mu \mathrm{g} / \mathrm{ml}$ of lysozyme (this study)

From $S$ by successive transfers in milk + $100 \mu \mathrm{g} / \mathrm{ml}$ of lysozyme (this study)

Derivatives of R100P by novobiocin treatment (this study)

\section{Acquisition of lysozyme resistance}

Acquisition of lysozyme resistance was obtained by successive transfers in skim milk containing $100 \mu \mathrm{g} / \mathrm{ml}$ of lysozyme as described previously (Neviani et al, 1991).

\section{Obtention of lysozyme-resistant variants}

Single colony isolates from the plates containing 100 and $500 \mu \mathrm{g} / \mathrm{ml}$ of lysozyme were tested for lysozyme resistance in milk containing 0 and $100 \mu \mathrm{g} / \mathrm{ml}$ of lysozyme by conductance measurements as described previously (Neviani et al, 1991). They were considered as "lysozyme resistant variants" when no difference $(< \pm 4 \%)$ in conductance parameters among the cultures was observed.

\section{Physiological and biochemical tests}

Phenotypic changes among lysozyme resistant R500 variants and $R 100$ cured derivatives were examinated for carbohydrate fermentation, enzymatic activity patterns, antibiotic sensitivity, $\mathrm{NaCl}$ resistance and acid production. Tests were performed as described previously (Neviani et al, 1991).

\section{Plasmid analysis}

Plasmid screenings were performed as described by Simon et al (1985), with some modifications.

Plasmid DNA was analyzed in $0.7 \%$ horizontal agarose gel in TBE buffer $(89 \mathrm{mM}$ Tris, 89 $\mathrm{mM}$ boric acid, 2 mM EDTA, pH 8.3) (Maniatis et al, 1982). Molecular mass of plasmids were esti- 
mated as described by Meyers et al (1976), with supercoiled ladder (BRL) as DNA size marker.

\section{Plasmid curing}

Plasmid loss was effected by overnight growth in MRS broth containing novobiocin (Sigma No N1628). MRS broth was inoculated with different concentrations $(0.01$ to $100 \mu \mathrm{g} / \mathrm{ml})$ of novobiocin and incubated at $37{ }^{\circ} \mathrm{C}$ and $40{ }^{\circ} \mathrm{C}$. A MRS broth tube containing a novobiocin concentration similar to that present in the last tube exhibiting visible growth was inoculated at $2 \%$ and incubated the same manner as the last tube.

\section{Restriction enzymes}

Restriction enzymes were purchased from Boehringer (Mannheim) and used according to the manufacturer's instructions.

\section{Total DNA extraction}

Preparation of total DNA was performed using the method of Loureiro dos Santos and Chopin (1987).

\section{RESULTS}

\section{Individual cell resistance to lysozyme in a cell population of $L$ helveticus}

When a $L$ helveticus culture grown in milk without lysozyme was enumerated in MRS agar containing progressive concentrations of lysozyme, 2 thresholds of lysozyme resistance were observed at 50 and $300 \mu \mathrm{g} / \mathrm{ml}$ (fig 1). The concentration of cells resistant to the $100 \mu \mathrm{g} / \mathrm{ml}$ of lyso-

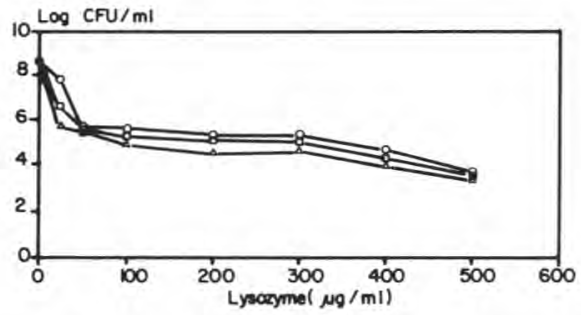

Fig 1. Growth of Lactobacillus helveticus strains $4 \mathrm{~S}, 11 \mathrm{~S}$ and $31 \mathrm{~S}$ in presence of different concentrations of lysozyme. Enumeration in MRS agar with $0-500 \mu \mathrm{g} / \mathrm{ml}$ of lysozyme. Strains 4S: $-0-, 11 \mathrm{~S}:-\Delta-, 31 \mathrm{~S}:-\square-$. Croissance des souches de Lactobacillus helveticus $4 \mathrm{~S}, 11 \mathrm{~S}$ et $31 \mathrm{~S}$ en présence de différentes concentrations de lysozyme. Dénombrement en gélose MRS avec $0-500 \mu \mathrm{g} / \mathrm{ml}$ de lysozyme. Souches $4 S:-0-11 S:-\Delta-$, $31 \mathrm{~S}:-\square$ -

zyme threshold, chosen for selecting resistant derivatives, was $\approx 105 / \mathrm{ml}$ (fig 1 ).

As shown in table II, the ratios of cells resistant to 100 or $500 \mu \mathrm{g} / \mathrm{ml}$ increased during the successive transfers of strains 4 $\mathrm{S}, 11 \mathrm{~S}, 27 \mathrm{~S}$ and $31 \mathrm{~S}$ in milk containing $100 \mu \mathrm{g} / \mathrm{ml}$ of lysozyme. After the final transfer that exhibited complete resistance - as determined by conductance measurements - the whole population was found to be resistant to $100 \mu \mathrm{g} / \mathrm{ml}$ of lysozyme. Though the selection threshold was fixed at $100 \mu \mathrm{g} / \mathrm{ml}$, the percentage of cells resistant to $500 \mu \mathrm{g} / \mathrm{ml}$ of lysozyme was increased significantly up to $100 \%$ of cells for strains $11 \mathrm{~S}, 27 \mathrm{~S}$ and $31 \mathrm{~S}$ (table II). For lysozyme concentrations $>500 \mu \mathrm{g} / \mathrm{ml}$, the percentage of resistant cells decreased progressively (fig 2). The ratio of resistant to sensitive cells obtained at $3000 \mu \mathrm{g} / \mathrm{ml}$ of lysozyme, that is to say $10^{-5}$, was higher than the frequency of spontaneous mutation. 
Table II. Acquisition of lysozyme resistance during successive transfers in milk containing $100 \mu \mathrm{g} / \mathrm{ml}$ of lysozyme. Enumeration in MRS agar with indicated lysozyme concentration.

Acquisition de la résistance au lysozyme au cours de passages successifs dans du lait contenant 100 $\mu \mathrm{g} / \mathrm{ml}$ de lysozyme. Dénombrement en gélose MRS contenant la concentration indiquée de lysozyme.

Strain Transfer's number

CFU/mI

Lysozyme concentration $(\mu \mathrm{g} / \mathrm{ml})$

0

100

500

\begin{tabular}{|c|c|c|c|c|}
\hline \multirow[t]{4}{*}{$4 S$} & 0 & $3.1 \times 10^{8}$ & $2.8 \times 10^{6}$ & $1.6 \times 10^{4}$ \\
\hline & 1 & $5.3 \times 10^{7}$ & $7.2 \times 10^{6}$ & $6.5 \times 10^{4}$ \\
\hline & 2 & $7.9 \times 10^{7}$ & $1.0 \times 10^{7}$ & $1.9 \times 10^{6}$ \\
\hline & 3 & $2.1 \times 10^{8}$ & $2.1 \times 10^{8}$ & $6.0 \times 10^{6}$ \\
\hline \multirow[t]{5}{*}{$11 S$} & 0 & $1.9 \times 10^{8}$ & $1.2 \times 10^{4}$ & $1.3 \times 10^{4}$ \\
\hline & 1 & $1.1 \times 10^{8}$ & $7.8 \times 10^{5}$ & $1.7 \times 10^{5}$ \\
\hline & 2 & $1.0 \times 10^{8}$ & $1.0 \times 10^{7}$ & $6.3 \times 10^{5}$ \\
\hline & 3 & $1.3 \times 10^{8}$ & $3.8 \times 10^{7}$ & $3.8 \times 10^{6}$ \\
\hline & 4 & $8.5 \times 10^{7}$ & $1.5 \times 10^{8}$ & $5.0 \times 10^{7}$ \\
\hline \multirow[t]{4}{*}{$31 \mathrm{~S}$} & 0 & $1.5 \times 10^{8}$ & $1.2 \times 10^{6}$ & $1.5 \times 10^{3}$ \\
\hline & 1 & $1.1 \times 10^{8}$ & $7.0 \times 10^{6}$ & $1.1 \times 10^{5}$ \\
\hline & 2 & $1.8 \times 10^{7}$ & $1.1 \times 10^{7}$ & $1.1 \times 10^{7}$ \\
\hline & 3 & $1.7 \times 10^{8}$ & $1.7 \times 10^{8}$ & $2.3 \times 10^{8}$ \\
\hline \multirow[t]{3}{*}{$27 \mathrm{~S}$} & 0 & $1.4 \times 10^{8}$ & $2.6 \times 10^{3}$ & $<1.0 \times 10^{2}$ \\
\hline & 1 & $1.5 \times 10^{7}$ & $1.7 \times 10^{7}$ & $1.3 \times 10^{3}$ \\
\hline & 2 & $8.8 \times 10^{6}$ & $8.6 \times 10^{6}$ & $7.6 \times 10^{6}$ \\
\hline
\end{tabular}

\section{Detection of lysozyme resistant variants}

Fifty single colony isolates from plates containing $100 \mu \mathrm{g} / \mathrm{ml}$ of lysozyme were tested for lysozyme resistance using conductance measurements: no derivative resistant to $100 \mu \mathrm{g} / \mathrm{ml}$ (ie with no observed difference in conductance parameters during growth in milk containing 0 and $100 \mu \mathrm{g} / \mathrm{ml}$ of lysozyme) was obtained.

Conversely all the 20 single colony isolates from plates containing $500 \mu \mathrm{g} / \mathrm{ml}$ of lysozyme were found resistant to $100 \mu \mathrm{g} /$ $\mathrm{ml}$ of lysozyme. These R500 variants (ta- ble I) showed full resistance to $100 \mu \mathrm{g} / \mathrm{ml}$ of lysozyme in milk for all tested cell concentrations as confirmed by both the similar conductance curves and detection times (DT), except for the smaller cell concentration of strain 31 R500 (table III). The generation time (GT) of variant 31 R500 was slightly longer in the presence of lysozyme (table IV) : this last observation was strictly related to the enzyme activity at low cell concentrations. The ratio of cells to enzyme could play a role in explaining this phenomenon. The GT of variants 4 R500 and 11 R500 were not affected by the presence of the enzyme and confirmed the high resistance of these strains. 


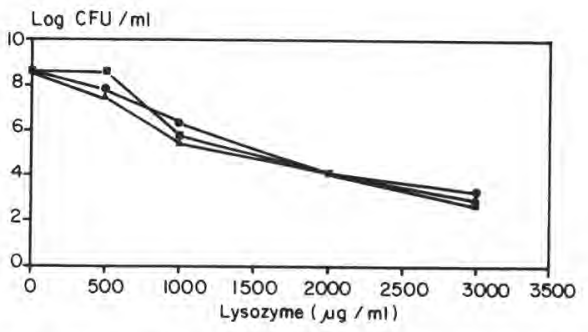

Fig 2. Growth of Lactobacillus helveticus strains $4 \mathrm{R} 500,11 \mathrm{R} 500$ and $31 \mathrm{R} 500$ in presence of different concentrations of lysozyme. Enumeration in MRS agar with $0-3000 \mu \mathrm{g} / \mathrm{ml}$ of lysozyme. Strains 4 R500 :- 11 R500 :- 31 R500:- 준.

Croissance des souches de Lactobacillus helveticus $4 R 500,11 R 500$ et 31 R500 en présence de différentes concentrations de lysozyme. Dénombrement en gélose MRS avec $0-3000 \mu \mathrm{g} /$ $\mathrm{ml}$ de lysozyme. Souches 4 R500: $\longrightarrow, 11$ R500:-4-, 31 R500:

If compared to control cultures, the GT of R500 variants (table IV) appeared similar for strains 4 and 11 and higher for strain 31.

\section{Physiological and biochemical tests}

Differences in carbohydrate fermentation and enzymatic activity patterns between both series of strains ( $S$ and R500) were not observed. Furthermore, antibiotic (ampicillin, chloramphenicol, erythromycin, kanamycin, novobiocin, polymyxin, rifamycin, streptomycin, tetracycline) sensitivity patterns were similar. All the strains were able to grow in the presence of $2 \% \mathrm{NaCl}$ and were inhibited by $5 \% \mathrm{NaCl}$. No difference in $\mathrm{pH}$ curves was observed among all $\mathrm{S}$ strains and their R500 variants.

\section{Detection of resistant derivatives harboring a 11.5-kb plasmid}

Plasmid profiles were determined for the 8 strains used in isolating $L$ helveticus derivatives resistant to lysozyme (Neviani et al, 1991). No differences in plasmid profiles were observed for 5 strains, but, as shown in figure 3 , unexpected results were obtained with 3 strains 4,11 and 31 : whereas the sensitive strains were plasmid-free, the resistant derivatives harbored a single plasmid with a molecular mass of $\approx 11.5$ $\mathrm{kb}$.

A B C D E F G H

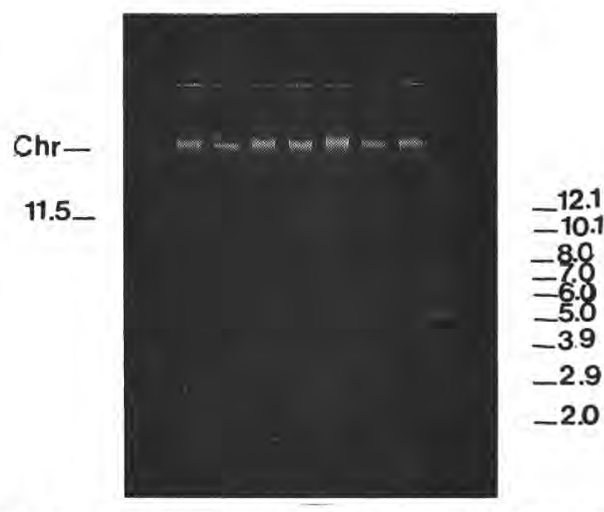

Fig 3. Agarose gel electrophoresis of plasmid DNA isolated from some Lactobacillus helveticus strains used in this study. A, $4 \mathrm{~S} ; \mathrm{B}, 11 \mathrm{~S}$; C, 31 S; D, 4 R100P; E, 11 R100P; F, 31 R100P; G, 31 R100P-15; H, molecular mass marker (supercoiled ladder-BRL) designated in $\mathrm{kb}$. Chr, chromosomal DNA band.

Electrophorèse en gel d'agarose d'ADN plasmidique isolé de souches de Lactobacillus helveticus utilisées dans cette étude. A, $4 S$; $B, 11$ S; C, 31 S; D, 4 R100P; E, 11 R100P; F, 31, R100P; G, 31 R100P-15; $H$, marqueur de masse moléculaire (supercoiled ladder BRL) exprimé en kb. Chr, bande de l'ADN chromosomal. 
Table III. Resistance of Lactobacillus helveticus R500 variants to $100 \mu \mathrm{g} / \mathrm{ml}$ of lysozyme. Conductimetric assay referred to different initial cell concentrations. Growth in milk with (+ lys) or without (- lys) $100 \mu \mathrm{g} / \mathrm{ml}$ of lysozyme.

Résistance au lysozyme des variants R500 de Lactobacillus helveticus. Essais conductimétriques effectués à partir de différentes concentrations initiales de cellules. Croissance dans du lait avec (+ lys) ou sans (-lys) $100 \mu \mathrm{g} / \mathrm{ml}$ de lysozyme.

\begin{tabular}{|c|c|c|c|c|c|c|}
\hline \multirow{3}{*}{$\begin{array}{l}\text { No of } \\
\text { bacteria/ml }\end{array}$} & \multicolumn{6}{|c|}{ Detection time $(h)$} \\
\hline & \multicolumn{2}{|c|}{ Strain 4 R500 } & \multicolumn{2}{|c|}{ Strain $11 R 500$} & \multicolumn{2}{|c|}{ Strain 31 R500 } \\
\hline & $-l y s$ & + lys & $-l y s$ & + lys & $-l y s$ & + lys \\
\hline \multirow[t]{2}{*}{$10^{6}$} & 1.2 & 2.2 & 2.0 & 2.0 & 2.1 & 2.1 \\
\hline & 1.5 & 2.2 & 4.7 & 2.6 & 2.8 & 2.6 \\
\hline \multirow[t]{2}{*}{$10^{5}$} & 4.7 & 4.7 & 5.3 & 5.7 & 6.2 & 6.1 \\
\hline & 4.8 & 4.9 & 5.4 & 6.6 & 6.7 & 6.7 \\
\hline \multirow[t]{2}{*}{$10^{4}$} & 8.2 & 7.9 & 11.6 & 12.4 & 11.7 & 12.5 \\
\hline & 8.3 & 7.9 & 12.5 & 14.3 & 11.9 & 12.9 \\
\hline \multirow[t]{2}{*}{$10^{3}$} & 13.0 & 12.3 & 14.8 & 16.0 & 15.6 & 16.0 \\
\hline & 14.1 & 13.1 & 15.1 & 16.1 & 16.0 & 16.3 \\
\hline \multirow[t]{2}{*}{$10^{2}$} & 15.8 & 14.7 & 18.0 & 19.7 & 18.0 & 19.0 \\
\hline & 16.0 & 16.5 & 18.0 & 21.0 & 18.9 & 20.0 \\
\hline \multirow[t]{2}{*}{$10^{1}$} & 18.5 & 18.3 & 22.3 & 22.2 & 21.3 & 25.0 \\
\hline & 19.1 & 19.1 & 22.6 & 23.2 & 21.4 & 26.8 \\
\hline \multirow[t]{2}{*}{$10^{0}$} & 19.9 & 20.2 & 24.5 & 23.6 & 23.6 & 25.0 \\
\hline & 22.2 & 21.8 & 26.4 & 28.3 & 24.3 & 26.8 \\
\hline
\end{tabular}

A number of problems arise from the presence of these strains, labelled 4 R100P, 11 R100P and 31 R100P (table I), namely : i), what is their origin? ii), what is the competitive advantage during growth in milk containing lysozyme? iii), has the plasmid, which is apparently common to the 3 strains, a function in this competitive advantage? Further experiments have been planned to attempt to answer these questions.

\section{Possible origin of R100P strains}

The experiments of growth in milk containing $100 \mu \mathrm{g} / \mathrm{ml}$ of lysozyme were repeated from the initial stock of strains $4 \mathrm{~S}, 11 \mathrm{~S}$ and $31 \mathrm{~S}$. All of the R100 derivatives obtained were devoid of plasmids. Therefore, it was impossible to intentionally reproduce the emergence of R100P strains harboring the $11.5-\mathrm{kb}$ plasmid. 
Table IV. Resistance to lysozyme of Lactobacillus helveticus R500 variants: GT of the cultures with and without the enzyme. $r=$ correlation coefficient of the regression line used to calculate GT. Growth in milk with (+ lys) or without (- lys) $100 \mu \mathrm{g} / \mathrm{ml}$ of lysozyme. " from Neviani et al (1991).

Résistance au lysozyme des variants R500 de Lactobacillus helveticus: GT des cultures avec et sans l'enzyme. $\mathrm{r}=$ coefficient de corrélation de la droite de régression utilisée pour calculer GT (temps de génération). Croissance dans du lait avec (+ lys) ou sans (- lys) $100 \mu \mathrm{g} / \mathrm{ml}$ de lysozyme. ${ }^{+}$d'après Neviani et al (1991).

\begin{tabular}{|c|c|c|c|c|c|}
\hline \multirow[t]{2}{*}{ Strains } & \multicolumn{2}{|c|}{$G T$} & \multicolumn{2}{|c|}{$r$} & \multirow{2}{*}{$\frac{G T^{*}}{-l y s}$} \\
\hline & $-1 y s$ & + lys & - lys & + lys & \\
\hline $4 \mathrm{R} 500$ & 62 & 60 & 0.990 & 0.992 & \\
\hline $11 R 500$ & 70 & 73 & 0.990 & 0.983 & \\
\hline $31 R 500$ & 67 & 84 & 0.990 & 0.998 & \\
\hline $4 S$ & & & & & 60 \\
\hline $11 \mathrm{~S}$ & & & & & 67 \\
\hline $31 S$ & & & & & 56 \\
\hline
\end{tabular}

The R100P strains were screened in cultures from single colonies obtained by enumeration of $S$ trains in MRS agar containing 100 or $500 \mu \mathrm{g} / \mathrm{ml}$ of lysozyme: no plasmid was found in the cultures examined.

Phenotypic characteristics were compared between $S$ strains and R100P derivatives: no difference was observed in the carbohydrate fermentation and enzymatic activity patterns or in resistance to antibiotics. Resistance of $\mathrm{S}$ strains to 2 bacteriophages that represent the 2 major groups specific to $L$ helveticus (Séchaud, unpublished observations), was also found in R100P derivatives. Restriction profiles of total DNA after digestion by EcoRI or HindIII enzymes exhibited no significant differences when R100P derivatives were compared to $\mathrm{S}$ strains.

As all the characteristics tested of $\mathrm{S}$ strains and R100 derivatives were similar, it follows that the R100 and R100P derivatives were not distinguishable except for the presence of the $11.5-\mathrm{kb}$ plasmid.

\section{Possible competition between R100 and $R$ 100P derivatives}

Single colony isolates from cultures of R100P strains on MRS agar containing $500 \mu \mathrm{g} / \mathrm{ml}$ of lysozyme were screened for the presence of the $11.5-\mathrm{kb}$ plasmid: $100 \%$ of isolates contained this plasmid in strains $4 \mathrm{R} 100 \mathrm{P}$ and $31 \mathrm{R} 100 \mathrm{P}$ and $50 \%$ of 11 R100P isolates. Thus, the original strains were then found to be totally or partially dominated by R100P derivatives.

As shown previously, the growth curve of $S$ strains and $R 100$ derivatives were similar, when growth was performed in milk with or without lysozyme. The same results were obtained when $S$ strains and their R100P derivatives were compared. It follows that growth curves of R100 and $\mathrm{R} 100 \mathrm{P}$ derivatives were similar.

Possible inhibition of R100 derivatives by $\mathrm{R} 100 \mathrm{P}$ derivatives was tested on MRS agar: no inhibition was observed. In conclusion, no direct proof of the superiority of derivatives R100P or R100 was obtained.

\section{Curing of the derivative 11 R100P}

One hundred clones were isolated after novobiocin treatment of the derivative 11 R100P and were tested for presence of the $11.5-\mathrm{kb}$ plasmid, as shown by electrophoresis: 10 clones were found to be apparently lacking this plasmid. Two of these cured clones $11 \mathrm{R} 100 \mathrm{P}^{-}-14$ and 11 
R100P- 15 , chosen at random, were compared to common parent strain 11 R100P.

Carbohydrate fermentation, enzymatic activity and $\mathrm{NaCl}$ resistance patterns were similar between $L$ helveticus 11 R100P and its cured derivatives $11 \mathrm{R} 100 \mathrm{P}-14$ and 15. Except for an increased resistance (from 50 to $200 \mathrm{U} / \mathrm{ml}$ ) to polymyxin, no difference was observed for the MIC of antibiotics and nisin.

Lysozyme resistance tested in milk containing $100 \mu \mathrm{g} / \mathrm{ml}$ of lysozyme by conductance measurements did not change for the cured derivative 11 R100P- 14 (fig 4), whereas it decreased for the cured derivative 11 R100P- 15 (fig 4). The MIC of lysozyme decreased from 400 for strain R100 to 100 and 50 for derivatives 11 R100P14 and 11 R100P- 15 respectively.

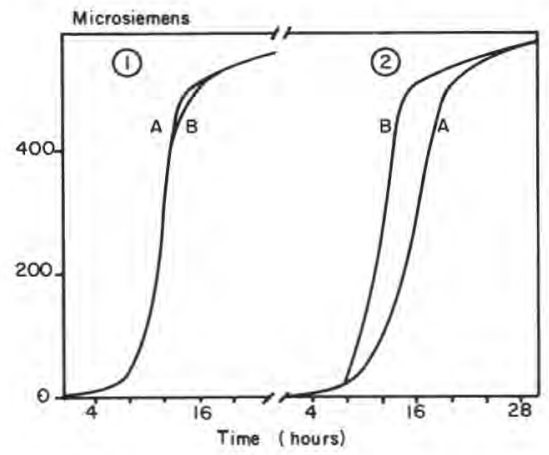

Fig 4. Curve of conductance of the Lactobacillus helveticus cured derivatives 11 R100P- 14 and 11 R100P-15. Growth in milk with (A) and without (B) $100 \mu \mathrm{g} / \mathrm{ml}$ of lysozyme of derivatives 11 R100P- 14 (curve 1) and 11 R100P- 15 (curve 2). Initial cell concentration $104 / \mathrm{ml}$.

Courbe de conductance des dérivés curés de Lactobacillus helveticus R100P-14 et R100 P15. Croissance dans du lait avec (A) et sans (B) $100 \mu \mathrm{g} / \mathrm{ml}$ de lysozyme des dérivés 11 R100P14 (courbe 1) and 11 R100P- 15 (courbe 2). Concentration initiale de cellules $10^{4} / \mathrm{ml}$.

\section{DISCUSSION}

The data presented here indicate that resistance to lysozyme for individual cells varied largely in a cell population of $L$ helveticus strains sensitive to lysozyme. In particular, the ratio of cells with a resistance level equal to the selection threshold $(100 \mu \mathrm{g} / \mathrm{ml})$ for resistant strains (Neviani et al, 1988) was relatively significant $(0.1 \%)$. Furthermore, a noticeable fraction of the population was resistant to a concentration of lysozyme $(500 \mu \mathrm{g} / \mathrm{ml})$ higher that this selection threshold.

The ratio of cells resistant to $100 \mu \mathrm{g} / \mathrm{ml}$ of lysozyme is largely higher than the frequency of spontaneous mutation. Therefore, $L$ helveticus could be considered naturally resistant to lysozyme, but, as a result of the large variability of individual cell resistances, resistance to lysozyme cannot be demonstrated for $L$ helveticus by analyzing the properties of the whole population.

Variability in resistance to methicillin has been described for Staphylococcus aureus (Gutmann and Goldstein, 1985). For the majority of strains designated as "heterogeneous", only a fraction $\left(10^{-4}\right.$ to $10^{-6}$ ) of the cell population could express methicillin resistance. However, some "homogeneous" strains expressed this resistance for almost the entire population. It is noteworthy that methicillin resistance is linked to peptidoglycan synthesis. By analogy with this variability in $S$ aureus, $L$ helveticus $S$ strains sensitive to lysozyme appear as "heterogeneous" whereas R100 derivatives resistant to $100 \mu \mathrm{g} / \mathrm{ml}$ of lysozyme are "homogeneous".

However, variability in individual cell resistance was also found in the cell populations of $L$ helveticus R100 strains. Therefore, the R100 strains are not "homogeneous" for the resistance to con- 
centrations of lysozyme higher $500 \mu \mathrm{g} / \mathrm{ml}$. It would appear, then, that the increase of resistance to lysozyme in $L$ helveticus was always obtained by a modification of the phenotypic expression. By contrast, gene mutation was apparently required to obtain derivatives of $M$ lysodeikticus resistant to lysozyme (Brumfitt, 1959).

Heterogeneity of resistance to lysozyme may result from a variability in the phenotypic expression of the resistance, since a heterogeneous population was obtained from a single clone. This conclusion is in agreement with the presumed mechanism of lysozyme resistance for $L$ helveticus (Neviani et al, 1991) : variability of the phenotypic expression appears to result from quantitative variation in the chemical composition of each individual cell wall and in the rate of synthesis of new cell wall material.

The partial growth inhibition observed in milk with lysozyme (Neviani et al, 1991) could be explained either by an increase in the division time for the whole population, or by the lack of cell division for some daughter cells. The data presented here are in agreement with this latter mechanism: during successive transfers, the cell population was enriched in cells resistant to $100 \mu \mathrm{g} / \mathrm{ml}$ of lysozyme and also in cells resistant to $500 \mu \mathrm{g} / \mathrm{ml}$ of lysozyme. The selection pressure in milk containing lysozyme seems to work by stopping cell multiplication of the more sensitive fraction of the cell population.

The partial growth inhibition by lysozyme in sensitive strains was observed for some oral bacteria (lacono et al, 1980), and therefore could be interpreted as a variability of the phenotypic expression of resistance, as in $L$ helveticus. Otherwise, the lower growth rate of resistant variants in $M$ lysodeikticus (Litwack, 1958; Brumfitt, 1959) could mean that these resistant variants were not homogeneous. Consequently, the hypothesis of the variability in the phenotypic expression of the resistance to lysozyme, as substantiated for $L$ helveticus, could be extended to other bacterial species and considered as a general phenomenon.

Since the clones isolated from plates containing $500 \mu \mathrm{g} / \mathrm{ml}$ of lysozyme are resistant to $100 \mu \mathrm{g} / \mathrm{ml}$ of lysozyme, it should be possible to obtain in one step a homogeneous population resistant to a given concentration of lysozyme by selecting clones from cultures grown on solid medium containing a lysozyme concentration markedly higher that the given one. This procedure would be a promising alternative to serial subcultures in milk (Neviani et al, 1988; 1991).

The origin of the R500P strains harboring a $11.5-\mathrm{kb}$ plasmid that were obtained from cultures in milk inoculated with strains lacking this plasmid has not been directly demonstrated. However, since R500P strains exhibited a growth curve in milk similar to that observed for the parent strain and its derivatives R100 and R500, it is quite conceivable that R500P strains constitute a minor part of the initial population of the $S$ strains. Alternatively, the plasmid could be integrated in the chromosome of $S$ strains and may excise occasionally from the chromosomal DNA during growth in the presence of lysozyme. It has been shown that 2 plasmid-like elements are normally integrated in the chromosome of Bacteroides uniformis and that they are excised and appear as closedcircular forms only if Bacteroides uniformis is grown in the presence of tetracycline (Shoemaker and Salyers, 1988).

There is no simple explanation based either on differential growth rate in milk or on inhibition of growth to account for the emergence of R500P strains during selection in milk containing lysozyme. However, considering the large variability in individual resistance to lysozyme, one possibility is that a narrower amplitude of variability would reduce the percentage of the de- 
scendants that do not divide at a given concentration of lysozyme.

It is attractive to believe that the $11.5-\mathrm{kb}$ plasmid, although not essential for the resistance increase, may play an active role in expression of resistance to lysozyme. This speculation is based on the observation that the loss of the $11.5-\mathrm{kb}$ plasmid was associated with a decrease in lysozyme resistance for the entire population. However, in the absence of an effective tool for transferring DNA into $L$ helveticus cells, it is not possible at the present time to confirm this hypothesis. Previous studies (Batt, 1986; Morelli et al, 1986; Smiley and Fryder, 1978; de los Reyes-Gavilan et al, 1990) on possible plasmid-encoded functions in $L$ helveticus have encountered the same difficulties.

\section{ACKNOWLEDGMENTS}

We thank MC Chopin and A Chopin for helpful discussion and support throughout the course of this work. DA Winters' contribution for improving the translation of this paper is gratefully acknowledged.

\section{REFERENCES}

Araki Y, Nakatani T, Nakayama K, Ito E (1972) Occurrence of $\mathrm{N}$-nonsubstituted glucosamine residues in peptidoglycan of lysozymeresistant cell walls from Bacillus cereus. J Biol Chem 247, 6312-6322

Batt CA (1986) Genetic engineering of Lactobacillus. Food Technol 52, 95-112

Brumfitt W (1959) The mechanism of development of resistance to lysozyme by some Gram-positive bacteria and its results. $\mathrm{Br} J$ Exp Pathol 40, 441-450

De los Reyes-Gavilan CG, Limsowtin GKY, Séchaud L, Veaux M, Accolas JP (1990) Evidence for a plasmid-linked restrictionmodification system in Lactobacillus helveticus. Appl Environ Microbiol 56, 3412-3419
De Man JC, Rogosa M, Sharpe ME (1960) A medium for the cultivation of lactobacilli. $J$ Appl Bacteriol 23, 130-135

Gutmann L, Goldstein F (1985) Staphylocoques et beta-lactamines. In: L'antibiogramme (Courvalin P, Goldstein F, Philippon A, Sirot J, eds) MPC, Brussels, 23-28

lacono VJ, MacKay BJ, DiRienzo S, Pollock JJ (1980) Selective antibacterial properties of lysozyme for oral microorganisms. Infect $/ \mathrm{m}$ mun 29, 623-632

Litwack G (1958) Development of Micrococus lysodeikticus resistant to lysozyme. Nature $181,1348-1350$

Loureiro dos Santos AL, Chopin A (1987) Shotgun cloning in Streptococcus lactis. FEMS Microbiol Lett 42, 209-212

Maniatis F, Frisch EF, Sambock T (1982) Molecular Cloning. A Laboratory Manual, Cold Spring Harbor Laboratory, Cold Spring Harbor, NY

Meyers JA, Sanchez D, Eldwell LP, Falkows S (1976) Simple agarose gel electrophoresis method for the identification and characterization of plasmid deoxyribonucleic acid. J Bacteriol 127, 1529-1537

Morelli L, Vescovo M, Cocconcelli PS, Bottazzi $V(1986)$ Fast and slow milk coagulating variants of Lactobacillus helveticus HLM1. Can J Microbiol 32, 758-760

Neviani E, Carminati D, Giraffa G, Carini S (1988) Sensibilita dei batteri lattici al lisozima. Nota II: acquisizione di resistenza da parte di ceppi sensibili. Ind Latte 24, 27-34

Neviani E, Carminati D, Veaux M, Hermier J, Giraffa G (1991) Characterisation of Lactobacillus helveticus strains resistant to lysozyme. Lait 71

Salton MRJ (1961) The anatomy of the bacterial surface. Bact Rev 25, 77-99

Shoemaker NB, Salyers AA (1988) Tetracyclinedependent appearance of plasmid-like forms in Bacteroides uniformis 0061 mediated by conjugal Bacteroides tetracycline resistance elements. J Bacteriol 170, 1651-1657

Simon D, Rouault A, Chopin MC (1985) Protoplast transformation of group $N$ streptococci with cryptic plasmids. FEMS Microbiol Lett $26,239-241$

Smiley MB, Fryder (1978) Plasmid, lactic acid production and $\mathrm{N}$-acetyl $\mathrm{D}$-glucosamine fermentation in Lactobacillus helveticus subsp jugurti. Appl Environ Microbiol 35, 777-781 